\title{
Differences between fellows and fellowship program directors in their perception of the impact of the COVID-19 pandemic on gastroenterology training: results from a nationwide survey in Greece
}

\author{
George Karampekos ${ }^{\mathrm{a} *}$, Paraskevas Gkolfakis ${ }^{\mathrm{b*}}$, Georgios Tziatzios ${ }^{c *}$, Pericles Apostolopoulos ${ }^{\mathrm{d}}$, \\ Jiannis Vlachogiannakos ${ }^{e}$, Konstantinos Thomopoulos ${ }^{f}$, Andreas Protopapas", \\ Alexandros Kofokotsios ${ }^{\text {h, }}$ Michalis Oikonomou', Maria Mela a , Dimitrios Samonakisj, \\ Dimitrios Christodoulou' ${ }^{k}$, Konstantinos Triantafyllouc
}

"Evangelismos-Ophthalmiatreion Athinon - Polykliniki" General Hospital of Athens, Greec; Erasme University Hospital, Université Libre de Bruxelles, Brussels, Belgium; Medical School, National and Kapodistrian University of Athens, "Attikon" University General Hospital, Athens, Greece; NIMTS Hospital, Athens, Greece; Laiko General Hospital, Medical School, National and Kapodistrian University of Athens, Athens, Greece; University General Hospital of Patras, Patras, Greece; Aristotle University of Thessaloniki, AHEPA Hospital, Thessaloniki, Greece; “Euromedica Geniki Kliniki” General Hospital, Thessaloniki, Greece; Gastroenterology Private Practice Facility, Athens, Greece; University Hospital of Heraklion, Crete, Greece; University Hospital \& Faculty of Medicine, School of Health Sciences, University of Ioannina, Ioannina, Greece

\section{Abstract}

Background Lockdown measures applied during the SARS-CoV-2 outbreak caused a significant disturbance to hospital routine. We assessed trainees' and fellowship directors' perceptions regarding the impact of the pandemic on gastroenterology fellowship training.

Methods A web-based survey was anonymously disseminated to all Greek gastroenterology fellows and fellowship program directors. Participants completed electronically a questionnaire comprised of 5 domains that assessed participants' perception of: 1) overall impact on training; 2) impact on training in gastroenterology-specific fields (endoscopy, inflammatory bowel disease, hepatology); 3) impact on different aspects of endoscopy training; 4) impact on academic training; and 5) training perspectives for the post-pandemic era.

Results A total of 77/128 fellows (60.1\%) and 18/28 fellowship program directors (64.3\%) responded. More fellows reported that the COVID-19 pandemic would have an adverse impact on fellowship training compared to their fellowship program directors $(81.8 \%$ vs. $55.6 \%, \mathrm{P}=0.038)$. This concern was mainly focused on endoscopy training ( $83.1 \%$ vs. $27.8 \%, \mathrm{P}<0.001)$, with no difference regarding training in gastroenterology's other specific fields. The difference was consistent for technical skills (79.2\% vs. $38.9 \%, \mathrm{P}=0.001)$, and for the performance of basic diagnostic $(70.1 \%$ vs. $22.2 \%, \mathrm{P}<0.001)$ and emergency $(48.1 \%$ vs. $11.1 \%, \mathrm{P}=0.004)$ procedures. Fellows and fellowship program directors identified the unknown timeframe of measure implementation and the postponement of scheduled endoscopic procedures as the main factors that negatively affected training. Extension of the fellowship training program was deemed the optimal option by fellows for addressing the training decrement in the post-pandemic era, while fellowship program directors favored an increase in workload.

Conclusion Fellows and their fellowship program directors do not share the same concerns about the impact of COVID-19 pandemic on training programs and they propose different measures to remedy its effects.

Keywords Fellows, gastroenterology, COVID-19, training, survey

Ann Gastroenterol 2020; 33 (6): 1-7

Correspondence to: Konstantinos Triantafyllou, MD, PhD, Associate Professor of Gastroenterology, Second Department of Internal Medicine - Propaedeutic, Research Institute and Diabetes Center, Medical School, National and Kapodistrian University, Attikon University General Hospital, 1, Rimini Street, 12462 Athens, Greece, e-mail: ktriant@med.uoa.gr

Received 23 July 2020; accepted 29 September 2020; published online 12 October 2020

DOI: https://doi.org/10.20524/aog.2020.0546

* These authors contributed equally to this work

\section{Introduction}

Caused by an extremely virulent pathogen, with a potential for developing into a devastating pneumonia, COVID-19 has forced most countries to enact strict social distancing programs, or even complete lockdown of non-essential commercial activity. Nearly all affected countries have stopped performing elective endoscopy, with the majority of emergency procedures undertaken by certified endoscopists with minimal staff 
presence [1]. Countries more affected by the pandemic have allocated their staff, including those in training, to the service of units dealing with COVID-19 patients [2]. Greece, while having only a moderate disease burden that never exceeded the healthcare system's capacity, has postponed nearly all elective medical and surgical procedures since March 23, 2020. Many of the hospitals that served as gastroenterology training centers acted as tertiary referential centers for COVID-19 patients. In other countries this measure led to a re-allocation of gastroenterology fellows to other clinics, with a detrimental impact on their training [3]. In view of the controlled restart of elective activities, the Governing Board of the Hellenic Society of Gastroenterology (HSG) decided to perform a survey to assess the perceptions of fellows and their fellowship program directors on the effects of the lockdown on gastroenterology training.

\section{Materials and methods}

\section{Study population and survey design}

This was a cross-sectional web-based survey carried out in Greece in May 2020. The survey was distributed nationwide to all gastroenterology fellows $(n=128)$ and fellowship program directors $(n=28)$.

\section{Development and content of the questionnaire}

Based on the available literature [3-7], a team of researchers (PG, GT, DC and KT) with previous experience in questionnaire

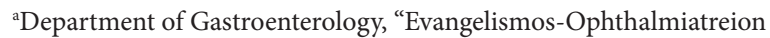
Athinon - Polykliniki” General Hospital of Athens, Greece (George Karampekos, Maria Mela); ${ }^{b}$ Department of Gastroenterology Hepatopancreatology and Digestive Oncology, Erasme University Hospital, Université Libre de Bruxelles, Brussels, Belgium (Paraskevas Gkolfakis); 'Hepatogastroenterology Unit, Second Department of Internal Medicine - Propaedeutic, Research Institute and Diabetes Center, Medical School, National and Kapodistrian University of Athens, "Attikon" University General Hospital, Athens, Greece (Georgios Tziatzios, Konstantinos Triantafyllou); ${ }^{\mathrm{d}}$ Gastroenterology Department, NIMTS Hospital, Athens, Greece (Pericles Apostolopoulos); 'Academic Department of Gastroenterology, Laiko General Hospital, Medical School, National and Kapodistrian University of Athens, Athens, Greece (Jiannis Vlachogiannakos); fDepartment of Gastroenterology, University General Hospital of Patras, Patras, Greece (Konstantinos Thomopoulos); ${ }^{\text {FFirst Propedeutic }}$ Department of Internal Medicine, Medical School, Aristotle University of Thessaloniki, AHEPA Hospital, Thessaloniki, Greece (Andreas Protopapas); ${ }^{\mathrm{h}}$ Department of Interventional Gastroenterology, "Euromedica Geniki Kliniki" General Hospital, Thessaloniki, Greece (Alexandros Kofokotsios); ${ }^{i}$ Gastroenterology Private Practice Facility, Athens, Greece (Michalis Oikonomou); ${ }^{\text {Department of }}$ Gastroenterology, University Hospital of Heraklion, Crete, Greece (Dimitrios Samonakis); kDivision of Gastroenterology, University Hospital \& Faculty of Medicine, School of Health Sciences, University of Ioannina, Ioannina, Greece (Dimitrios Christodoulou)

Conflict of Interest: None construction designed 2 similar survey instruments for fellows and fellowship program directors. Each instrument consisted of 2 sections: demographics and professional characteristics, and the main core of the questionnaire. In both questionnaires, the latter section consisted of the same 20 questions, classified into 5 distinctive domains, assessing participants' perception of the effect of the COVID-19 outbreak on: 1) the overall impact on training; 2) the impact on training in gastroenterology-specific fields (endoscopy, inflammatory bowel disease, hepatology); 3) the impact on different aspects of endoscopy training; 4) the impact on academic training; and 5) perspectives regarding training in the post-pandemic era. Finally, fellows were asked about the number of diagnostic endoscopiesesophagogastroduodenoscopy and colonoscopy-they had performed monthly, before and during the lockdown. The questionnaire with the 20 questions answered by both groups is presented in Supplementary Table 1.

\section{Administration of survey instrument}

The final versions of both questionnaires were approved by the Governing Board of the HSG. We used the commercially available version of the web-based survey program "Google forms" to develop this survey. The survey was distributed using the official HSG databases, by sending individualized e-mail invitations with the link to complete the survey, along with a

$\underline{\text { Table } 1 \text { Participants' demographics, n (\%) }}$

\begin{tabular}{|c|c|}
\hline Characteristics & Value \\
\hline \multicolumn{2}{|l|}{ Fellows $(n=77)$} \\
\hline \multicolumn{2}{|l|}{ Sex, n (\%) } \\
\hline Male & $52(67.5)$ \\
\hline Female & $25(32.5)$ \\
\hline \multicolumn{2}{|l|}{ Age, n (\%) } \\
\hline$\leq 30$ & $17(22.1)$ \\
\hline $31-35$ & $38(49.4)$ \\
\hline $36-40$ & $15(19.5)$ \\
\hline$\geq 41$ & $7(9.0)$ \\
\hline \multicolumn{2}{|l|}{ Year of training, $\mathrm{n}(\%)$} \\
\hline $1^{\text {st }}$ & $13(16.9)$ \\
\hline $2^{\text {nd }}$ & $19(24.7)$ \\
\hline $3^{\text {rd }}$ & $19(24.7)$ \\
\hline $4^{\text {th }}$ & $26(33.7)$ \\
\hline \multicolumn{2}{|l|}{ Number of fellows, n (\%) } \\
\hline$\leq 4$ & $22(28.6)$ \\
\hline $5-6$ & $36(46.8)$ \\
\hline$\geq 7$ & $19(24.6)$ \\
\hline \multicolumn{2}{|l|}{ Fellowship program directors $(n=18)$} \\
\hline Years practicing gastroenterology, mean (SD) & $25.8(5)$ \\
\hline Years being director, mean (SD) & $9.8(6)$ \\
\hline \multicolumn{2}{|l|}{ Number of fellows, n (\%) } \\
\hline$\leq 4$ & $11(61.1)$ \\
\hline $5-6$ & $5(27.8)$ \\
\hline$\geq 7$ & $2(11.1)$ \\
\hline
\end{tabular}


cover letter explaining its purposes. Duplicate participation was prevented by the electronic survey program itself, since only a single response per user was possible. The first call was sent out on May 1, 2020, 6 weeks after the implication of the national lockdown, and a reminder was sent 2 weeks later. Responses were automatically recorded in the system and entered into a software database (Microsoft Excel; Microsoft Corp., Redmond, WA, USA), while remaining anonymous to study investigators.

\section{Study endpoints}

The purpose was to assess Greek fellows' and fellowship program directors' perceptions regarding the impact of the COVID-19 outbreak on gastroenterology training. While the survey focused mainly on endoscopy training, it also assessed overall gastroenterology training and other specific fields of gastroenterology (inflammatory bowel disease and hepatology).

\section{Statistical analysis}

Quantitative data were expressed as mean \pm standard deviation (SD) or median (interquartile range [IQR]) depending on their distribution. Categorical data were represented as number (\%). The Kolmogorov-Smirnov statistic was used to assess the distribution of quantitative data for normality. We used nonparametrical tests to analyze categorical and non-continuous quantitative variables. For the purposes of the analysis "negative" and "very negative" answers were classified as negative, while "positive" and "very positive" answers were grouped as positive. All calculations were performed using the software statistical program Statistical Packages for Social Sciences (SPSS) version 25.0 (Chicago, Illinois, USA), with a P-value $<0.05$ considered as significant for all statistical assessments.

\section{Ethical considerations}

The study's protocol was approved by the Governing Board of the HSG. Participation was voluntary and anonymous. Survey completion did not require registration of unique physician identifiers. All participants were informed about the confidentiality of the data collected, as well as the voluntary nature of the survey.

\section{Results}

\section{Participants' characteristics}

A total of 77 of 128 fellows and 18 of 28 fellowship program directors completed the survey (response rates $64.3 \%$ and $60.1 \%$, respectively). Among fellows, 32 (41.6\%) of them were in the 2 first years of the fellowship. The monthly diagnostic endoscopy volume performed by fellows during the COVID-19 outbreak significantly decreased compared to that prior to the pandemic: median: 10 (IQR 2.5-20) vs. 50 (IQR 30-75), $\mathrm{P}<0.001$. As far as fellowship program directors are concerned, they had practiced gastroenterology for $25.8 \pm 5$ years and had served for $9.8 \pm 6$ years as fellowship program directors. The demographic characteristics of the participants are shown in Table 1 .

\section{Study endpoints}

\section{Participants' perspectives of COVID-19 outbreak impact on} gastroenterology training

The majority of fellows conveyed that the COVID-19 pandemic would exert a negative impact on their training in gastroenterology overall, while fellowship program directors retained a more conservative attitude: 63 (81.8\%) vs. 10 (55.6\%), $\mathrm{P}=0.038$, Table 2, questions 1-8. Supplementary Table 2 summarizes the distribution of answers among both respondent groups according to their baseline demographic characteristics. Regarding the overall impact of COVID-10 pandemic on gastroenterology training, no difference was detected among fellows $(\mathrm{P} \geq 0.205)$ and program directors $(\mathrm{P} \geq 0.188)$ according to their main demographic characteristics. Significantly more trainees in departments with more than 7 fellows expressed their concerns that the lack of protective equipment in the context of the COVID-19 pandemic might affect their training compared to departments with $<7$ fellows ( $94.7 \%$ vs. $65.5 \% ; \mathrm{P}=0.029$ ).

\section{Factors associated with negative impact on training}

Overall, there were no significant differences between fellows and program directors regarding factors potentially associated with a negative impact on training $(\mathrm{P}=0.274$; Fig. 1A). Both groups agreed that the unknown timeframe of measure implementation $(87.0 \%$ and $83.3 \%)$, the cancellation of scheduled endoscopic procedures $(83.1 \%$ and $66.7 \%)$, the reduction of endoscopies performed by fellows $(62.3 \%$ and $44.4 \%$ ), the redeployment of fellows in a COVID-19 treating department $(20.8 \%$ and $22.2 \%)$ and the reduction of training time in the outpatient clinic $(10.4 \%$ and $27.8 \%)$ were the main factors that could negatively affect fellows' training (Fig. 1A). However, more fellows than fellowship program directors identified the lack of time due to potential involvement with COVID-19 patients, as well as the lack of protective equipment, as additional contributors that negatively affected training: 60 (77.9\%) vs. 9 (50\%), $\mathrm{P}=0.036$, and $56(72.7 \%)$ vs. $6(33.3 \%)$, $\mathrm{P}=0.003$, respectively.

Participants' perspectives of COVID-19 outbreak impact on training in specific fields of gastroenterology

Significantly more fellows than fellowship program directors expressed concerns about the negative impact of the 
Table 2 Differences in perceptions of trainees and trainers regarding the impact of COVID-19 outbreak on different fields of gastroenterology fellowship programs

\begin{tabular}{|c|c|c|c|c|c|c|c|}
\hline \multirow[t]{2}{*}{ Questions } & \multicolumn{3}{|c|}{ Fellows, n (\%) } & \multicolumn{3}{|c|}{ Fellowship program directora, $\mathrm{n}(\%)$} & \multirow[t]{2}{*}{ P-value } \\
\hline & $\begin{array}{l}\text { Negative } \\
\text { very negative }\end{array}$ & $\begin{array}{l}\text { No } \\
\text { impact }\end{array}$ & $\begin{array}{l}\text { Positive } \\
\text { very positive }\end{array}$ & $\begin{array}{l}\text { Negative } \\
\text { very negative }\end{array}$ & $\begin{array}{l}\text { No } \\
\text { impact }\end{array}$ & $\begin{array}{c}\text { Positive } \\
\text { very positive }\end{array}$ & \\
\hline $\begin{array}{l}\text { Question 1: Impact on overall training in } \\
\text { gastroenterology }\end{array}$ & $63(81.8)$ & $13(16.9)$ & $1(1.3)$ & $10(55.6)$ & $8(44.4)$ & $0(0)$ & 0.038 \\
\hline $\begin{array}{l}\text { Question 2: Impact on training from limited } \\
\text { available time due to potential involvement with } \\
\text { patients suffering from COVID-19 }\end{array}$ & $60(77.9)$ & $17(22.1)$ & $0(0)$ & $9(50)$ & $9(50)$ & $0(0)$ & 0.036 \\
\hline $\begin{array}{l}\text { Question 3: Impact on training from not knowing } \\
\text { the timeframe of measure implementation in the } \\
\text { hospital }\end{array}$ & $67(87)$ & $9(11.7)$ & $1(1.3)$ & $15(83.3)$ & $3(16.7)$ & $0(0)$ & 0.762 \\
\hline Question 4: Impact of lack of protective equipment & $56(72.7)$ & $21(27.3)$ & $0(0)$ & $6(33.3)$ & $12(66.7)$ & $0(0)$ & 0.003 \\
\hline $\begin{array}{l}\text { Question 5: Impact of postponing of scheduled } \\
\text { endoscopic procedures (e.g., screening colonoscopy) }\end{array}$ & $64(83.1)$ & $13(16.9)$ & $0(0)$ & $12(66.7)$ & $6(33.3)$ & $0(0)$ & 0.186 \\
\hline $\begin{array}{l}\text { Question 7: Impact on training due to cancellation } \\
\text { of in-hospital training opportunities }\end{array}$ & $54(70.1)$ & $23(29.9)$ & $0(0)$ & $10(55.6)$ & $8(44.4)$ & $0(0)$ & 0.270 \\
\hline $\begin{array}{l}\text { Question 8: Impact on training due to cancellation } \\
\text { of national and European congresses }\end{array}$ & $66(85.7)$ & $11(14.3)$ & $0(0)$ & $12(66.7)$ & $6(33.3)$ & $0(0)$ & 0.084 \\
\hline $\begin{array}{l}\text { Question 9: Impact on training in treating patients } \\
\text { with general gastroenterology diseases }\end{array}$ & $56(72.7)$ & $21(27.3)$ & $0(0)$ & $10(55.6)$ & $8(44.4)$ & $0(0)$ & 0.167 \\
\hline $\begin{array}{l}\text { Question 10: Impact on training in treating patients } \\
\text { with inflammatory bowel diseases }\end{array}$ & $50(64.9)$ & $26(33.8)$ & $1(1.3)$ & $8(44.4)$ & $9(50)$ & $1(5.6)$ & 0.192 \\
\hline $\begin{array}{l}\text { Question 11: Impact on training in treating patients } \\
\text { with diseases of the liver }\end{array}$ & $48(62.3)$ & $27(35.1)$ & $2(2.6)$ & $8(44.4)$ & $10(55.6)$ & $0(0)$ & 0.243 \\
\hline $\begin{array}{l}\text { Question 12: Impact on acquiring/maintaining } \\
\text { competence regarding endoscopic skills }\end{array}$ & $64(83.1)$ & $13(16.9)$ & $0(0)$ & $5(27.8)$ & $13(72.2)$ & $0(0)$ & $<0.001$ \\
\hline $\begin{array}{l}\text { Question 13: Impact on the technical domain (i.e., } \\
\text { torque steering, loop-reduction techniques) of } \\
\text { fellows' endoscopy competence }\end{array}$ & $61(79.2)$ & $16(20.8)$ & $0(0)$ & $7(38.9)$ & $11(61.1)$ & $0(0)$ & 0.001 \\
\hline $\begin{array}{l}\text { Question 14: Impact on the cognitive domain of } \\
\text { fellows' endoscopy competence }\end{array}$ & $52(67.5)$ & $24(31.2)$ & $1(1.3)$ & $8(44.4)$ & $10(55.6)$ & $0(0)$ & 0.143 \\
\hline $\begin{array}{l}\text { Question 15: Impact on acquiring/maintaining } \\
\text { competence in performance of basic diagnostic } \\
\text { endoscopic procedures (gastroscopy/diagnostic } \\
\text { colonoscopy) }\end{array}$ & $54(70.1)$ & $23(29.9)$ & $0(0)$ & $4(22.2)$ & $12(77.8)$ & $0(0)$ & $<0.001$ \\
\hline $\begin{array}{l}\text { Question 16: Impact on acquiring/maintaining } \\
\text { competence in performance of emergency } \\
\text { endoscopic procedures }\end{array}$ & $37(48.1)$ & $40(51.9)$ & $0(0)$ & $2(11.1)$ & $16(88.9)$ & $0(0)$ & 0.004 \\
\hline $\begin{array}{l}\text { Question 17: Impact of electronic media and } \\
\text { alternative forms of education on acquiring/ } \\
\text { maintaining competence of fellows' endoscopic skills }\end{array}$ & $20(26)$ & $27(35)$ & $30(39)$ & $8(44.4)$ & $2(11.1)$ & $8(44.4)$ & 0.103 \\
\hline $\begin{array}{l}\text { Question 18: Impact on fellows' writing/scientific } \\
\text { training activity }\end{array}$ & $30(39)$ & $40(51.9)$ & $7(9.1)$ & $8(44.4)$ & $5(27.8)$ & $5(27.8)$ & 0.051 \\
\hline Question 19: Impact on fellows' academic activity & $33(42.9)$ & $41(53.2)$ & $3(3.9)$ & $9(50)$ & $6(33.3)$ & $3(16.7)$ & 0.078 \\
\hline
\end{tabular}

pandemic on acquiring/maintaining endoscopy competence: $64(83.1 \%)$ vs. $5(27.8 \%), \mathrm{P}<0.001$. Although numerically different, none of the differences between the 2 groups regarding the other specific fields of gastroenterology training were significant $(72.7 \%$ vs. $55.6 \%, \mathrm{P}=0.167$ for training in general gastroenterology, $64.9 \%$ vs. $44.4 \%, \mathrm{P}=0.192$ for training in inflammatory bowel diseases, and $62.3 \%$ vs. $44.4 \%, \mathrm{P}=0.243$ for hepatology training, respectively). The rates of negative, neutral and positive answers for each group are given in Table 2, questions 9-12. 


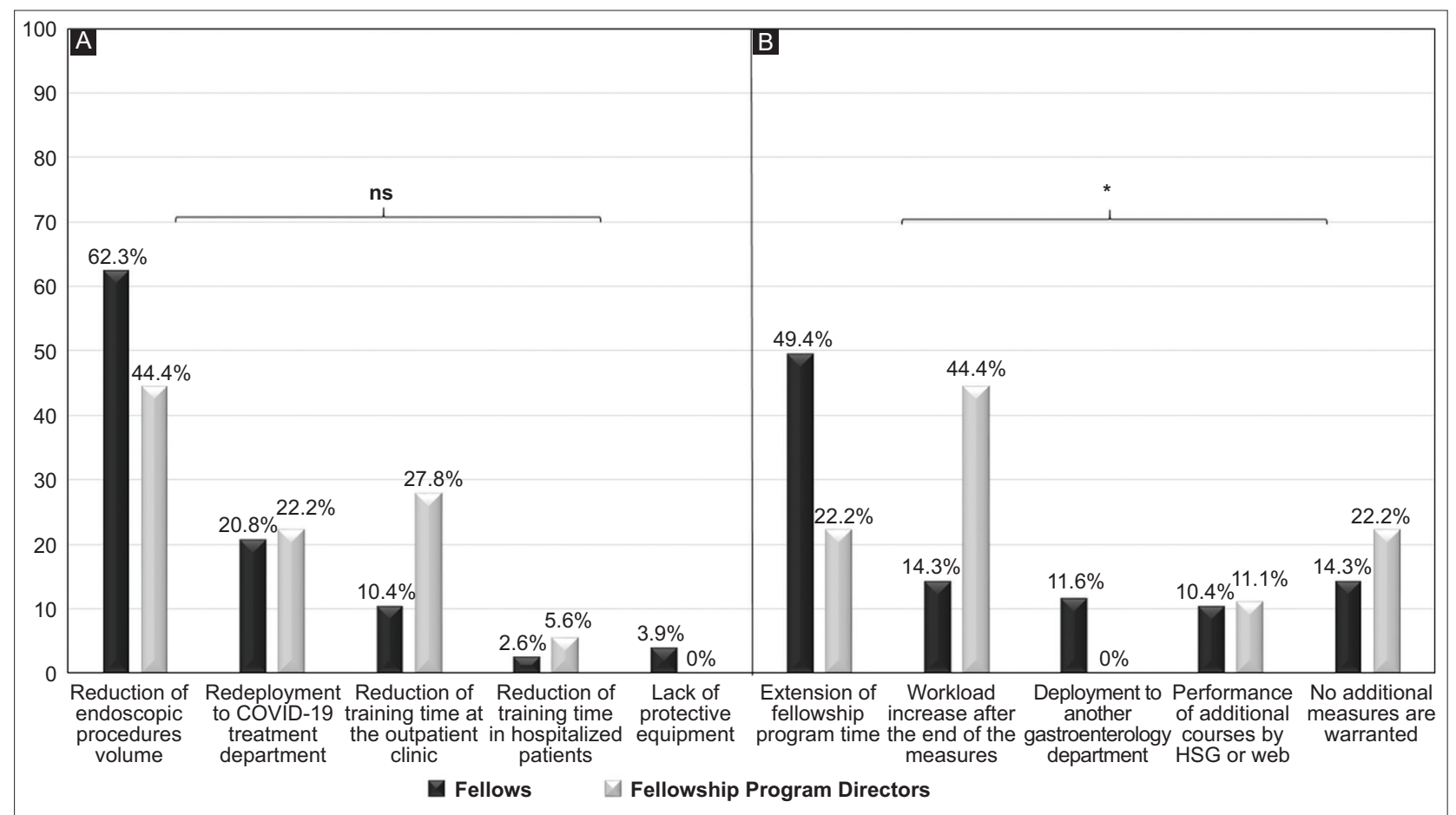

Figure 1 (A) Factors negatively affecting fellows' training during the COVID-19 pandemic (Question 6) and (B) Measures to improve fellows' training after the COVID-19 pandemic (Question 20)

${ }^{*}$ Denotes statistical significance

ns, not significant

\section{Participants' perspectives of COVID-19 outbreak impact on endoscopy subdomains}

Significantly more fellows than fellowship program directors expected a negative impact of COVID-19 outbreak on achieving competence and maintenance of technical skills in endoscopy: 61 (79.2\%) vs. 7 (38.9\%), $\mathrm{P}=0.001$. This difference between the two groups was also consistent as regards achieving competence in the performance of basic diagnostic and emergency procedures: 54 (70.1\%) vs. 4 (22.2\%), $\mathrm{P}<0.001$, and $37(48.1 \%)$ vs. 2 (11.1\%), $\mathrm{P}=0.004$, respectively. The difference regarding the impact on the cognitive domain of fellows' endoscopy competence did not reach significance: 52 (67.51\%) vs. 8 (44.4\%), $\mathrm{P}=0.14$, Table 2 , questions $13-17$. Interestingly, statistically significantly more fellows $\leq 30$ years old considered that the COVID-19 pandemic would negatively affect their training, in acquiring or maintaining competence in the performance of basic diagnostic endoscopic procedures, compared to their older colleagues: $100 \%$ vs. $61.7 \%$; $\mathrm{P}=0.013$ (Supplementary Table 2).

\section{Participants' perspectives of COVID-19 outbreak impact on academic training}

As shown in Table 2 (questions 18-19), there was no significant difference among fellows and their program directors regarding the potential impact of the COVID-19 pandemic on academic training. Interestingly, in both groups half or more of the participants considered that the pandemic would have either a positive or no impact on the fellows' scientific [47 (61\%) and 10 (55.6\%) for fellows and fellowship program directors, respectively] and academic [44 (57.1\%) and 9 (50\%), respectively] training.

\section{Strategies to address training in the post-pandemic era}

There was a significant difference between fellows and fellowship program directors regarding the optimal way to balance the training decrement in the post-pandemic era. Almost half (49.4\%) of the fellows proposed prolongation of the training period, while almost half of the program directors (44.4\%) favored an increase in the daily workload ( $\mathrm{P}=0.019$; Fig. 1B). Other options, such as redeployment in another gastroenterology department or participation in online courses were not deemed beneficial by either fellows or fellowship program directors (Fig. 1B).

\section{Discussion}

SARS-CoV-2 outbreak resulted in an unprecedented disruption of gastroenterology specialty training worldwide [8-11]. The results of this first web-based nationwide survey present valuable data regarding trainees' 
and fellowship directors' perceptions of the impact of the COVID-19 pandemic on gastroenterology fellowship training in Greece.

Our survey highlighted the fundamental concern of Greek gastroenterology fellows about the overall negative impact on training exerted by the COVID-19 pandemic. This newly encountered phenomenon has been at the focal point of other researchers worldwide. While our data were under analysis, 3 similar survey studies were published. Specifically, one international study, involving 770 trainees from 63 countries [8], reported that the pandemic led to restrictions in endoscopic volumes (99\%; IQR $85-100 \%$ reduction in all procedures) and endoscopy training, with high rates of anxiety and burnout, while a second questionnaire distributed to members of the Italian Young Gastroenterologist and Endoscopist Association and some European representatives, not including Greece [9], underlined the significant impact of the COVID-19 outbreak on gastroenterologists' clinical activity. Siau et al [11], in a survey across the United Kingdom (UK), noted a significant reduction in monthly endoscopy volume $(\mathrm{P}<0.001)$. It should be noted, however, that each of the abovementioned studies aimed at a different primary outcome and used its own, uniquely designed questionnaire, while the educational characteristics of the participants were not uniform, rendering direct comparisons to our results difficult. It is perhaps even more interesting that, in our study, fellowship program directors believed that a break of some weeks within a 4 -year training program might be ultimately associated with only a small decrement in fellows' overall abilities [12]. This is corroborated by the fact that lack of time due to potential involvement with COVID-19 patients, as well as the shortage of protective equipment, were identified only by fellows as major contributors that negatively affected the quality of training.

A reduction in the volume of endoscopies has been a common finding among all studies that investigated this issue [8-11]. Procedural volume has been inextricably linked to procedural competence $[4,13]$; however, whether the same finding applies to the era of the COVID-19 outbreak remains to be seen, since such implications at present time with the pandemic still underway are yet to be defined. Similarly to their European colleagues [9], study participants recognized that deployment in a COVID-19 treating department and a reduction in outpatient clinic activities as factors with an adverse impact on training.

Our study presents for the first time a handful of interesting observations derived from the participants' perspectives of the impact the COVID-19 outbreak will have on training in different fields of gastroenterology. Although statistical significance was not always reached, the proportion of fellows expressing concerns about the negative impact of the pandemic on endoscopy competence, as well on other specific fields of gastroenterology, surpassed that of the fellowship program directors. For all aspects of endoscopy (technical, diagnostic, emergency), fellows anticipated a statistically significant negative impact on their training, compared to their directors. Although short-term training breaks cause minimum disruption to fellows' training [12], one cannot exclude that a prolonged period of COVID-19 measures, together with existing evidence for high rates of anxiety and burnout among gastroenterology fellows [14], may affect trainees' perception about the impact of the pandemic on their endoscopic skills. On the other hand, directors showed fewer concerns about this matter, perhaps knowing that endoscopic competence needs a significant amount of time and procedural volume to be achieved; thus, the disruption would only be temporary and would not be able to influence training in its entirety.

Most of the fellows proposed prolongation of the fellowship training program, while fellowship program directors favored an increase in the daily workload. Training program prolongation could indeed be a potential measure; however, it is not without concerns (anxiety and burnout) for fellows, as was recently shown in a survey among UK gastroenterology trainees [11]. However, one should not forget that the UK and Greek healthcare systems are not directly comparable, since the two countries have not been equally affected by the pandemic. On the other hand, an increased workload further results not only in physical and emotional exhaustion, but also in fellows' perception of inadequate training [14]. Gastroenterology fellows ask for modifications of existing guidelines on training [11], with reforming of training curricula and rearranging of training activities among institutions [15,16]. Although limited, respondents had a positive attitude towards medical education delivery through online teaching and webinars. However, these methods might never replace the "traditional" methods of teaching and endoscopy performance in realworld circumstances.

This study had the following strengths. First, it is the first nationwide report to assess the perceptions of trainees and trainers regarding the impact of the COVID-19 outbreak on Greek gastroenterology fellows' training. Second, the examination of fellows' as well as fellowship program directors' perspectives on this important issue is considered a study asset. Finally, an equivalent response rate was achieved to those reported previously in similar studies $[8,9]$.

Limitations of this survey include the possibility of results being susceptible to recall and self-report bias, as with all studies of this particular type. Moreover, there is no validated instrument or questions; however, the questionnaire was designed based on the existing literature. Another limitation associated with the study's cross-sectional character might be considered the fact that these results just reflect a snapshot taken during the acceleration phase of COVID-19. Although a response rate of $60 \%$ could be considered as satisfactory, the fact that $40 \%$ of those initially invited did not return the questionnaire cannot not be overlooked. Finally, it should be underlined that the COVID-19 pandemic and its impact on education represent a dynamic process. Accordingly, conclusions should be viewed in the light that they may just reflect temporary and ephemeral opinions of the study's participants.

To conclude, Greek gastroenterology fellows are convinced that the COVID-19 outbreak will have a negative impact on their training, while training program directors are less 
concerned. Accurately identifying training gaps will assist local and international scientific societies to pursue new measures in order to address the educational needs of fellows during and after the COVID-19 pandemic.

\section{Acknowledgment}

The authors would like to thank all participants for their contribution to the study.

\section{Summary Box}

\section{What is already known:}

- COVID-19 has affected endoscopy services provision worldwide

- The impact on Greek gastroenterology fellows' training has not been evaluated

\section{What the new findings are:}

- Fellows and their fellowship program directors do not share the same concerns about the impact of the COVID-19 pandemic on training, and they propose different measures than their directors to remedy this situation

- The major concern of Greek gastroenterology fellows is training in endoscopy

\section{References}

1. Repici A, Maselli R, Colombo M, et al. Coronavirus (COVID-19) outbreak: what the department of endoscopy should know. Gastrointest Endosc 2020;92:192-197.

2. Lim EC, Oh VM, Koh DR, Seet RC. The challenges of "continuing medical education" in a pandemic era. Ann Acad Med Singap 2009;38:724-726.

3. Shah R, Satyavada S, Ismail M, et al. COVID-19 pandemic through the lens of a gastroenterology fellow: looking for the silver lining. Gastrointest Endosc 2020;92:394-398.
4. Fried GM, Marks JM, Mellinger JD, Trus TL, Vassiliou MC, Dunkin BJ. ASGE's assessment of competency in endoscopy evaluation tools for colonoscopy and EGD. Gastrointest Endosc 2014;80:366-367.

5. Gupta T, Nazif TM, Vahl TP, et al. Impact of the COVID-19 pandemic on interventional cardiology fellowship training in the New York metropolitan area: A perspective from the United States epicenter. Catheter Cardiovasc Interv 2020 May 16 [Online ahead of print]. doi: 10.1002/ccd.28977.

6. Gkolfakis P, Tziatzios G, Papadopoulos V, Dimitriadis GD, Georgopoulos SD, Triantafyllou K. A nationwide survey of training satisfaction and employment prospects among Greek gastroenterology fellows during the economic recession. Ann Gastroenterol 2017;30:242-249.

7. Mallon D, Pohl JF, Phatak UP, et al; NASPGHAN Training Committee COVID-19 Survey Working Group. Impact of COVID-19 on pediatric gastroenterology fellow training in North America. J Pediatr Gastroenterol Nutr 2020;71:6-11.

8. Pawlak KM, Kral J, Khan R, et al. Impact of COVID-19 on endoscopy trainees: an international survey. Gastrointest Endosc 2020;92:925-935.

9. Marasco G, Nardone OM, Maida M, Boskoski I, Pastorelli L, Scaldaferri F; Italian Association of Young Gastroenterologists and Endoscopists (AGGEI). Impact of COVID-19 outbreak on clinical practice and training of young gastroenterologists: A European survey. Dig Liver Dis 2020 May 23 [Online ahead of print]. doi: 10.1016/j.dld.2020.05.023.

10. Kumar S, Prenner S, Kochman ML. The impact of COVID-19 on endoscopic training. Am J Gastroenterol 2020;115:1142-1143.

11. Siau K, Iacucci M, Dunckley P, Penman I. The impact of COVID-19 on gastrointestinal endoscopy training in the United Kingdom. Gastroenterology 2020 Jun 15 [Online ahead of print]. doi: 10.1053/j.gastro.2020.06.015.

12. Jorgensen JE, Elta GH, Stalburg CM, et al. Do breaks in gastroenterology fellow endoscopy training result in a decrement in competency in colonoscopy? Gastrointest Endosc 2013;78:503-509.

13. Patel SG, Keswani R, Elta G, et al. Status of competency-based medical education in endoscopy training: a nationwide survey of US ACGME-accredited gastroenterology training programs. Am J Gastroenterol 2015;110:956-962.

14. Ayala-Morillas LE, Fuentes-Ferrer ME, Sánchez-Díaz J, RumayorZarzuelo M, Fernández-Pérez C, Marco-Martínez F. Factors associated with residents' satisfaction with their training as specialists. Rev Clin Esp (Barc) 2014;214:175-183.

15. Jafar W. COVID-19 and endoscopy training. Frontline Gastroenterol 2020;11:413-414.

16. Rees CJ, East JE, Oppong K, et al. Restarting gastrointestinal endoscopy in the deceleration and early recovery phases of COVID-19 pandemic: Guidance from the British Society of Gastroenterology. Clin Med (Lond) 2020;20:352-358. 


\section{Supplementary material}

Supplementary Table 1 The 20 questions used to evaluate both fellows' and fellowship program directors' perspectives regarding the potential impact of COVID-19 outbreak on training

Assessing participants' perspective regarding the potential impact of the coronavirus (COVID-19) outbreak on training

Please answer the following questions by choosing the most appropriate answer

\begin{tabular}{|c|c|c|c|c|c|c|}
\hline Q1 & $\begin{array}{l}\text { Do you think that the COVID-19 pandemic will affect } \\
\text { your/your fellows' training in gastroenterology, overall? }\end{array}$ & $\begin{array}{l}\text { Very } \\
\text { negative }\end{array}$ & Negative & $\begin{array}{l}\text { No impact/ } \\
\text { effect }\end{array}$ & Positive & Very positive \\
\hline Q2 & $\begin{array}{l}\text { Do you think that the limited available time due to } \\
\text { potential involvement with patients suffering from } \\
\text { COVID-19 will affect your/your fellows' training? }\end{array}$ & $\begin{array}{l}\text { Very } \\
\text { negative }\end{array}$ & Negative & $\begin{array}{l}\text { No impact/ } \\
\text { effect }\end{array}$ & Positive & Very positive \\
\hline Q3 & $\begin{array}{l}\text { Do you think that the unknown timeframe of measure } \\
\text { implementation in the hospital due to the COVID-19 } \\
\text { pandemic will affect your/your fellows' training? }\end{array}$ & $\begin{array}{l}\text { Very } \\
\text { negative }\end{array}$ & Negative & $\begin{array}{l}\text { No impact/ } \\
\text { effect }\end{array}$ & Positive & Very positive \\
\hline Q4 & $\begin{array}{l}\text { Do you think that the lack of protective equipment } \\
\text { in the context of the COVID-19 pandemic will affect } \\
\text { your/your fellows' training? }\end{array}$ & $\begin{array}{l}\text { Very } \\
\text { negative }\end{array}$ & Negative & $\begin{array}{l}\text { No impact/ } \\
\text { effect }\end{array}$ & Positive & Very positive \\
\hline Q5 & $\begin{array}{l}\text { Do you think that postponement of scheduled } \\
\text { endoscopic procedures (e.g., screening colonoscopy) } \\
\text { during the COVID-19 pandemic will affect your/your } \\
\text { fellows' training? }\end{array}$ & $\begin{array}{l}\text { Very } \\
\text { negative }\end{array}$ & Negative & $\begin{array}{l}\text { No impact/ } \\
\text { effect }\end{array}$ & Positive & Very positive \\
\hline Q6 & $\begin{array}{l}\text { Which of the following do you think that will } \\
\text { significantly affect your/your fellows' training during } \\
\text { the COVID-19 pandemic? }\end{array}$ & $\begin{array}{l}\text { Reduction of } \\
\text { endoscopic } \\
\text { procedures } \\
\text { volume }\end{array}$ & $\begin{array}{l}\text { Reduction of } \\
\text { training time } \\
\text { in hospitalized } \\
\text { patients }\end{array}$ & $\begin{array}{l}\text { Reduction of } \\
\text { training time at } \\
\text { the outpatient } \\
\text { clinic }\end{array}$ & $\begin{array}{l}\text { Redeployment } \\
\text { to COVID-19 } \\
\text { treatment } \\
\text { department }\end{array}$ & $\begin{array}{l}\text { Lack of } \\
\text { protective } \\
\text { equipment }\end{array}$ \\
\hline Q7 & $\begin{array}{l}\text { Do you think that the COVID-19 pandemic will affect } \\
\text { your/your fellows' training because of cancellation of } \\
\text { in-hospital training opportunities (e.g., cancellation } \\
\text { of intra-departmental and inter-departmental } \\
\text { postgraduate courses)? }\end{array}$ & $\begin{array}{l}\text { Very } \\
\text { negative }\end{array}$ & Negative & $\begin{array}{l}\text { No impact/ } \\
\text { effect }\end{array}$ & Positive & Very positive \\
\hline Q8 & $\begin{array}{l}\text { Do you think that the COVID-19 pandemic will affect } \\
\text { your/your fellows' training through the cancellation of } \\
\text { national and European congresses? }\end{array}$ & $\begin{array}{l}\text { Very } \\
\text { negative }\end{array}$ & Negative & $\begin{array}{l}\text { No impact/ } \\
\text { effect }\end{array}$ & Positive & Very positive \\
\hline Q9 & $\begin{array}{l}\text { Do you think that the COVID-19 pandemic will affect } \\
\text { your/your fellows' training in treating patients with } \\
\text { general gastroenterology diseases? }\end{array}$ & $\begin{array}{l}\text { Very } \\
\text { negative }\end{array}$ & Negative & $\begin{array}{l}\text { No impact/ } \\
\text { effect }\end{array}$ & Positive & Very positive \\
\hline Q10 & $\begin{array}{l}\text { Do you think the COVID-19 pandemic will affect } \\
\text { your/your fellows' training in treating patients with } \\
\text { inflammatory bowel diseases (IBD)? }\end{array}$ & $\begin{array}{l}\text { Very } \\
\text { negative }\end{array}$ & Negative & $\begin{array}{l}\text { No impact/ } \\
\text { effect }\end{array}$ & Positive & Very positive \\
\hline Q11 & $\begin{array}{l}\text { Do you think the COVID-19 pandemic will affect } \\
\text { your/your fellows' training in treating patients with } \\
\text { diseases of the liver? }\end{array}$ & $\begin{array}{l}\text { Very } \\
\text { negative }\end{array}$ & Negative & $\begin{array}{l}\text { No impact/ } \\
\text { effect }\end{array}$ & Positive & Very positive \\
\hline Q12 & $\begin{array}{l}\text { Do you think that the COVID-19 pandemic will affect } \\
\text { your/your fellows' training in acquiring/maintaining } \\
\text { competence regarding your endoscopic skills? }\end{array}$ & $\begin{array}{l}\text { Very } \\
\text { negative }\end{array}$ & Negative & $\begin{array}{l}\text { No impact/ } \\
\text { effect }\end{array}$ & Positive & Very positive \\
\hline Q13 & $\begin{array}{l}\text { Do you think that the COVID-19 outbreak will affect } \\
\text { the technical domain (i.e., torque steering, loop- } \\
\text { reduction techniques) of your/your fellows' endoscopy } \\
\text { competence? }\end{array}$ & $\begin{array}{l}\text { Very } \\
\text { negative }\end{array}$ & Negative & $\begin{array}{l}\text { No impact/ } \\
\text { effect }\end{array}$ & Positive & Very positive \\
\hline
\end{tabular}

$(\operatorname{Contd} \ldots)$ 
Assessing participants' perspective regarding the potential impact of the coronavirus (COVID-19) outbreak on training

Please answer the following questions by choosing the most appropriate answer

\begin{tabular}{|c|c|c|c|c|c|c|}
\hline Q14 & $\begin{array}{l}\text { Do you think that the COVID-19 outbreak will affect } \\
\text { the cognitive domain (application of endoscopically } \\
\text { derived information to clinical practice, i.e., knowledge } \\
\text { of procedural indications and contraindications, } \\
\text { involvement in real-time decisions on the urgency } \\
\text { and necessity of endoscopic procedures, pathology } \\
\text { identification) of your/your fellows' endoscopy } \\
\text { competence? }\end{array}$ & $\begin{array}{l}\text { Very } \\
\text { negative }\end{array}$ & Negative & $\begin{array}{l}\text { No impact/ } \\
\text { effect }\end{array}$ & Positive & Very positive \\
\hline Q15 & $\begin{array}{l}\text { Do you think that the COVID-19 pandemic will affect } \\
\text { your/your fellows' training, in acquiring/maintaining } \\
\text { competence in the performance of basic diagnostic } \\
\text { endoscopic procedures (gastroscopy/diagnostic } \\
\text { colonoscopy)? }\end{array}$ & $\begin{array}{l}\text { Very } \\
\text { negative }\end{array}$ & Negative & $\begin{array}{l}\text { No impact/ } \\
\text { effect }\end{array}$ & Positive & Very positive \\
\hline Q16 & $\begin{array}{l}\text { Do you think that the COVID-19 pandemic will affect } \\
\text { your/your fellows' training, in acquiring/maintaining } \\
\text { competence in the performance of emergency } \\
\text { endoscopic procedures (e.g., gastrointestinal bleeding, } \\
\text { foreign object removal)? }\end{array}$ & $\begin{array}{l}\text { Very } \\
\text { negative }\end{array}$ & Negative & $\begin{array}{l}\text { No impact/ } \\
\text { effect }\end{array}$ & Positive & Very positive \\
\hline Q17 & $\begin{array}{l}\text { Do you think that the use of electronic media and } \\
\text { alternative forms of education (e.g., online courses, } \\
\text { watching endoscopic videos) could be of value in } \\
\text { acquiring/maintaining competence in your/your } \\
\text { fellows' endoscopic skills? }\end{array}$ & $\begin{array}{l}\text { Very } \\
\text { negative }\end{array}$ & Negative & $\begin{array}{l}\text { No impact/ } \\
\text { effect }\end{array}$ & Positive & Very positive \\
\hline Q18 & $\begin{array}{l}\text { Do you think that the COVID-19 pandemic will affect } \\
\text { your/your fellows' writing/scientific training activity } \\
\text { (participation in scientific projects, writing scientific } \\
\text { articles)? }\end{array}$ & $\begin{array}{l}\text { Very } \\
\text { negative }\end{array}$ & Negative & $\begin{array}{l}\text { No impact/ } \\
\text { effect }\end{array}$ & Positive & Very positive \\
\hline Q19 & $\begin{array}{l}\text { Do you think that the COVID-19 pandemic will affect } \\
\text { your/your fellows' academic activity (preparation of a } \\
\text { doctoral thesis/participation in a postgraduate program)? }\end{array}$ & $\begin{array}{l}\text { Very } \\
\text { negative }\end{array}$ & Negative & $\begin{array}{l}\text { No impact/ } \\
\text { effect }\end{array}$ & Positive & Very positive \\
\hline Q20 & $\begin{array}{l}\text { Which of the following do you think could be } \\
\text { extremely influential in improving your/your fellows' } \\
\text { training after the COVID-19 pandemic? }\end{array}$ & $\begin{array}{l}\text { Extension of } \\
\text { fellowship } \\
\text { program } \\
\text { time }\end{array}$ & $\begin{array}{l}\text { Deployment } \\
\text { to a different } \\
\text { gastroenterology } \\
\text { department }\end{array}$ & $\begin{array}{l}\text { Performance } \\
\text { of additional } \\
\text { courses by } \\
\text { HSG or web }\end{array}$ & $\begin{array}{l}\text { Workload } \\
\text { increase after } \\
\text { the end of the } \\
\text { measures }\end{array}$ & $\begin{array}{l}\text { No additional } \\
\text { measures are } \\
\text { warranted }\end{array}$ \\
\hline
\end{tabular}




\begin{tabular}{|c|c|c|c|c|c|}
\hline$\vec{\partial}$ & & 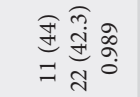 & 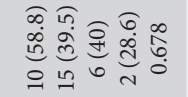 & 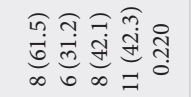 & 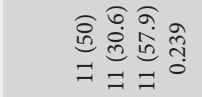 \\
\hline$\stackrel{\infty}{\vec{\sigma}}$ & & 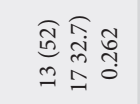 & 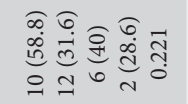 & 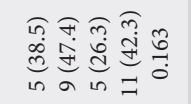 & 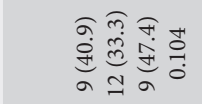 \\
\hline$\hat{\partial}$ & & 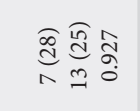 & 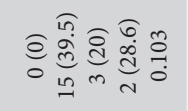 & 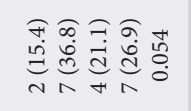 & 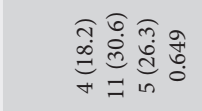 \\
\hline$\stackrel{\partial}{\partial}$ & & 尊商㫄芯 & 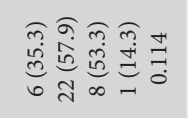 & 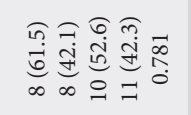 & 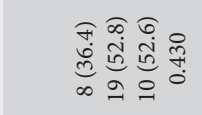 \\
\hline$\vec{z}$ & & 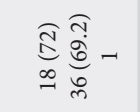 & 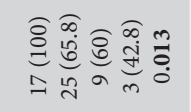 & 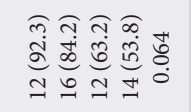 & 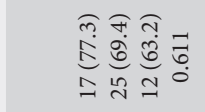 \\
\hline$\vec{\sigma}$ & & 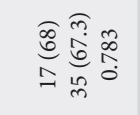 & 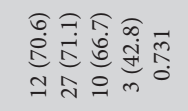 & 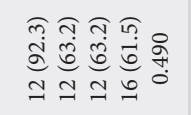 & 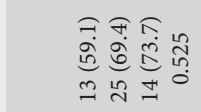 \\
\hline$\hat{\vec{\partial}}$ & & 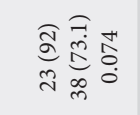 & 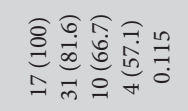 & 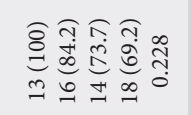 & 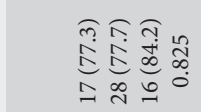 \\
\hline$\tilde{\sigma}$ & & 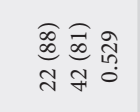 & 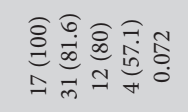 & 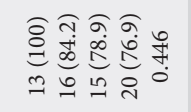 & 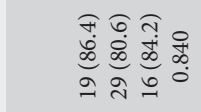 \\
\hline $\bar{\sigma}$ & & 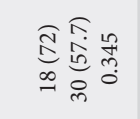 & 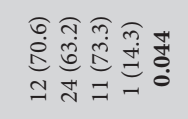 & 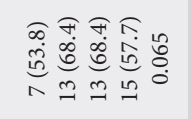 & 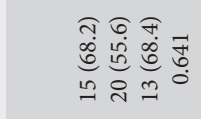 \\
\hline$\stackrel{\partial}{\partial}$ & & 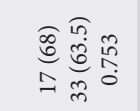 & 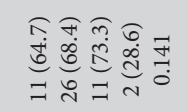 & 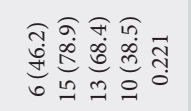 & 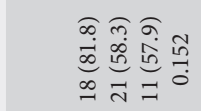 \\
\hline$\partial$ & 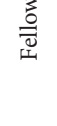 & 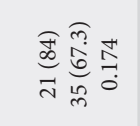 & 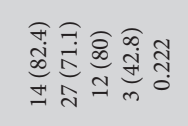 & 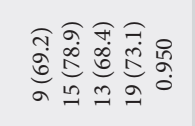 & 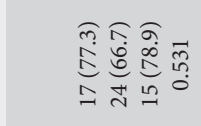 \\
\hline$\stackrel{\infty}{\infty}$ & & 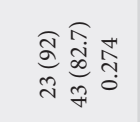 & 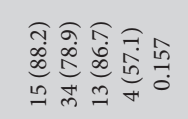 & 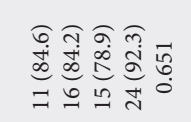 & 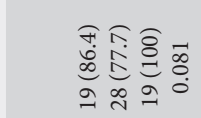 \\
\hline$\partial$ & & 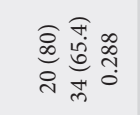 & 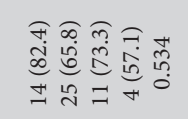 & 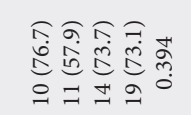 & 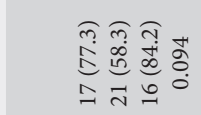 \\
\hline$\ddot{z}$ & & 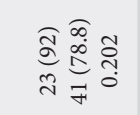 & 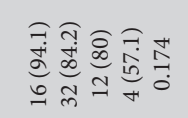 & 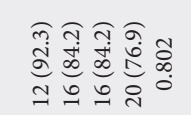 & 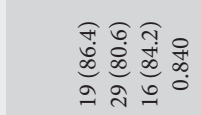 \\
\hline ठ & & 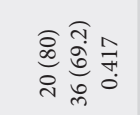 & 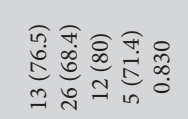 & 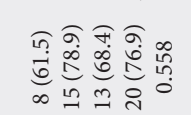 & 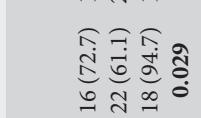 \\
\hline$\approx$ & & 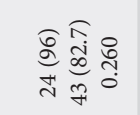 & 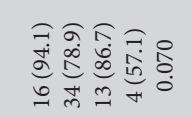 & 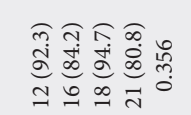 & 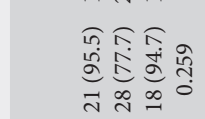 \\
\hline$\approx$ & & 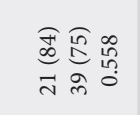 & 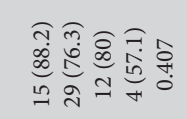 & 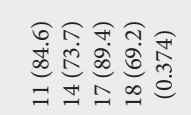 & 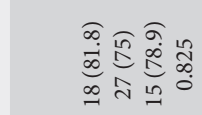 \\
\hline $\bar{\sigma}$ & & 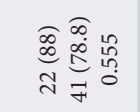 & 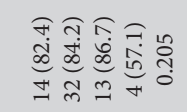 & 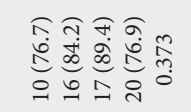 & 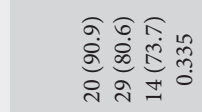 \\
\hline 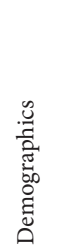 & & 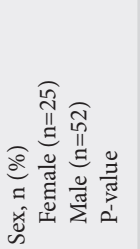 & 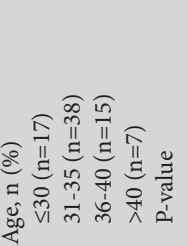 & 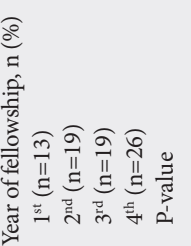 & 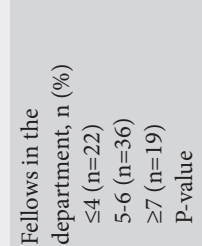 \\
\hline
\end{tabular}

\begin{tabular}{|c|c|c|c|}
\hline 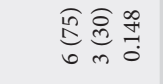 & & 命 & 递 \\
\hline 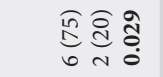 & & 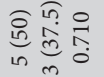 & 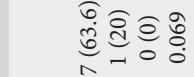 \\
\hline 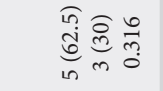 & & 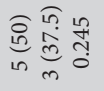 & $\begin{array}{l}\text { ñ } \\
\text { 馬 } \\
\text { in }\end{array}$ \\
\hline 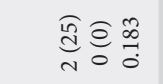 & & 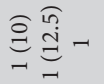 & 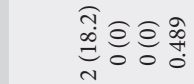 \\
\hline 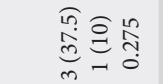 & & 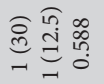 & 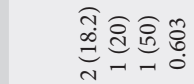 \\
\hline 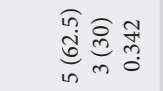 & & 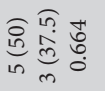 & 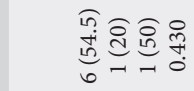 \\
\hline 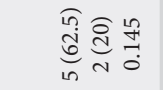 & & 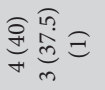 & 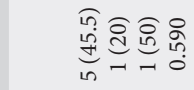 \\
\hline 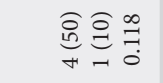 & & 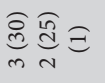 & 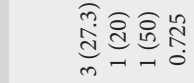 \\
\hline 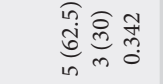 & & 它点 & 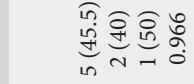 \\
\hline 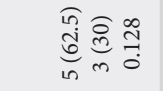 & & 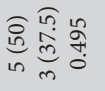 & 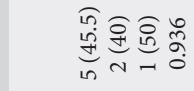 \\
\hline 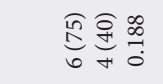 & & & 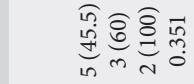 \\
\hline $\begin{array}{l}10 \\
0 \\
0 \\
0\end{array}$ & & 量究 & 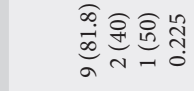 \\
\hline 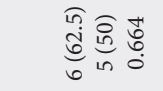 & & 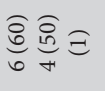 & 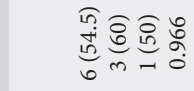 \\
\hline 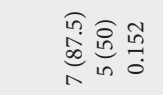 & & 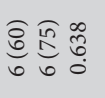 & 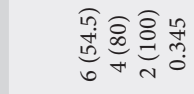 \\
\hline 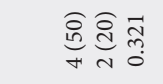 & & 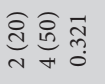 & 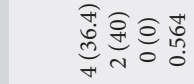 \\
\hline 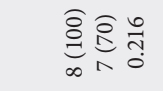 & & 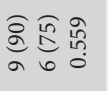 & 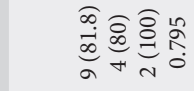 \\
\hline 究 & & 象啇 & 焉 \\
\hline 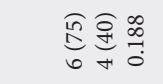 & s & 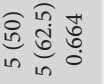 & 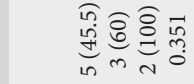 \\
\hline 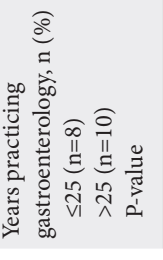 & 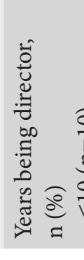 & 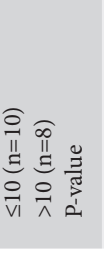 & 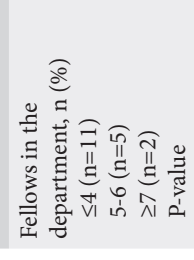 \\
\hline
\end{tabular}

